\title{
Water resources management in Australia during drought
}

\author{
A. Nourani ${ }^{1}$, S. Irfani ${ }^{2}$ \& H. M. Vosoughifar ${ }^{3}$ \\ ${ }^{1}$ Curtin University of Technology, Australia \\ ${ }^{2}$ University of Murdoch, Australia \\ ${ }^{3}$ University of Berkley, USA
}

\begin{abstract}
During history, humanity has been just a witness of droughts. To better perceive why society is still reacting to droughts rather than planning for their consequence, the activities of different levels of government in planning for droughts must be investigated. Until very recently, the policies of most Australian governments for dealing with drought have been to the state of waiting and in the meantime provide some form of emergency assistance to localities and hope the disaster can be over. The policies of the local governments also have been to provide emergency relief and to try to lessen water demand to match the available supply. This governmental approach, however, has not cut the economic losses or the level of inconvenience and suffering of the Australian citizens. In climatic terms, a drought can be defined as a pause of time, during which the actual moisture supply at a given place consistently is less than the climatically expected or climatically appropriate moisture supply. Water deficiencies can develop rather quickly in the root zone, most droughts are thought of as agricultural droughts. This characterization can be confusing. However, because an agricultural drought can occur in the midst of a hydrological wet period. The distribution of precipitation during a year can be such that there is a lack of moisture during a critical growing period for a variety of crops and the total precipitation for the year can be greater than the historical yearly average. This paper will provide an overview of Australian government approach to droughts, investigate obstacles to effective planning for droughts, political considerations and framework for state action.
\end{abstract}

Keywords: Australia, drought, agriculture, effective planning, management, action framework, governmental policy. 


\section{Obstacles to effective planning for droughts}

Although governments can plan effectively for droughts, fundamental problems that deter action need to be examined and understood before drought planning can become a reality. Four obstacles to planning for droughts-specificity, randomness, drought phenomenon and cost of droughts are discussed here.

\subsection{Specificity}

Planning for and management of perilous events presuppose that those events are well defined and perceptible to all. The planning necessary to cut down the effects of most natural hazards is challenging because the intensity and frequency of the events are unknown, although there is never any question as to their eventual happening. Although no technical expertise is demanded to determine when floods, earthquakes, or volcanic eruptions have been experienced, notable uncertainty exists as to when droughts begin and finish. Any discussion about planning for drought conditions and management of water resources, therefore, requires some definition as to what constitutes a drought. This lack of specificity can be a major factor, although unstated, as to why the planning for droughts and management of water resources during droughts have received less attention than they deserve.

\subsection{Randomness}

Droughts, when viewed in historical perspective, have not received much attention from governments at any level until severe lack of water occurs. What most inhibits the planning for lack of water associated with droughts is their random nature. It is this variability that makes "reacting" to a water-shortage crisis and instituting relief efforts when the shortages happen appear to be more rational than does "planning" for droughts. People are inclined to over-look that droughts are a normal part of the climatic regime and that they will recur. Droughts remain a certainty; only their severity and frequency are unknown. Therefore, it makes good sense to plan to reduce both the costs that result from droughts and pertaining personal hardships.

\subsection{Drought phenomenon}

Another barrier to planning for droughts is inherent in the drought phenomenon. Although droughts affect individuals, in fact droughts area community problem having characteristics of Hardin's famous "Tragedy of the Commons" (Yevjevich et al. [2]). The net result can well be the destruction or deterioration of the communal possession. In Hardin's example, the overgrazing and destruction of the common pastures occurred because each individual sought to graze all the animals. The sum of the actions by each person was not "best" for the sum of the individuals. This phenomenon makes the best policy impossible unless the individuals come to a consensus themselves or are made to do so by a government. 
For those experiencing a drought, options to deal with lack of water are limited. Collective action by all the individuals provides the best solution. What you capture is what you obtain, and those having the deepest wells and the biggest pumps get the most water. Given these circumstances, the solution for an individual during drought conditions might be to dig a well. If all individuals act in the same way, a variety of consequences can happen to the detriment of each. The individuals can be competitors for water and make larger and larger cones of depression as deeper wells and bigger pumps are utilized, or the increased pumping can cause saltwater intrusion, which will destroy the quality of the water in the aquifer. The best solution for all parties might be an agreement between the individual well owners, or restriction by the local government, to reduce the time and rate of pumping. Under these circumstances, an individual who pumps water from an aquifer cannot plan effectively for droughts. If an individual well owner seeks to conserve ground water or plan for a water shortage, he or she needs to be aware that the water he or she does not pump will probably be pumped by others.

Since droughts affect larger geographic areas more than single-occupied communities, the capability of an individual community to respond effectively is affected by communities in the drought area. The position of each community in this larger area can be comparable to that of the individual in the community. Individual actions by each community can be counter-productive to the region as a whole. For a community, the solution may be the building of a reservoir on a stream that is the water source for other communities downstream. As each community decides to resolve its water needs without regard to its neighbors, the stream can become an inadequate water source for all. The best solution might be development of a regional water supply for all communities, but this will demand the consensus of all of the communities.

\subsection{Cost of droughts}

The lack of information about the cost of droughts is another reason why only marginal interest exists in planning for droughts, especially at the State level. The magnitude of drought costs is assumed to be less than that of other natural hazards because the losses associated with other natural hazards are more evident and generally are incurred during short periods of time. In contrast, drought losses generally are distributed over longer time periods. When the true costs of drought are known, drought losses can dwarf the losses from other natural hazards. For example, Australia determined that, for the period 1941-70, the costs of droughts were three times the costs of other natural hazards (Heathcode [3]). In addition, all the costs associated with droughts are not clearly defined. The social effects of droughts and the associated costs, how the effects propagate throughout society, and who is ultimately affected need to be better understood. Human suffering is less likely to be factored into the cost assessment even though these costs are real and can continue for years, long after other costs have been absorbed. The aggregated indirect costs probably are far greater than the direct costs, but because of their diffused nature they are difficult to identify and quantify and, thus, generally go unrecognized (Yevjevich et al. [2]). These 
indirect costs, which are disbursed among large groups and throughout large geographic areas, nevertheless constitute a major proportion of the total costs resulting from droughts (Yevjevich et al. [2]).Again, the random nature of droughts, coupled with the rapid decrease of public interest in droughts after normal precipitation resumes and the limited resources available for planning, make the determination of in-direct costs associated with the droughts less urgent. As long as these indirect, diffused costs remain undisclosed, decision makers will have incomplete knowledge of the costs of drought. If the past is any guide, the total costs of droughts probably never will be reliably assessed. The length of a drought also has a significant effect on the total costs; long droughts are more costly than shorter droughts. A sustained drought, such as the one in the 1930s, can have economic and social costs that are never quantified. During the 2000s drought, for example, agriculture was abandoned in some sections; this abandonment, in turn, caused dislocation of people and severe impairment of the economic substructure that supported agriculture.

\section{Political considerations}

Lastly, political considerations affect action that might lessen the effects of droughts through better planning and management. The randomness of droughts induces the public to believe that little can be done to reduce the costs of droughts before they occur. In addition, the public's memory of past tragedies usually is short, and political attention shifts quickly to new political problems. The public, lacking an analysis of the total costs associated with a drought, has the illusion that droughts are affordable, although inconvenient. Thus, decision makers lack the public support needed to take aggressive action in planning for droughts and managing water resources during droughts. In contrast to a lack of public support, special-interest groups at the State level might oppose activities that are essential for an effective water-management plan applicable to droughts. For example, farm groups in Queensland strongly oppose any Governmental, State, or regional water-management plan because they believe there should be no regulation of water apart from the Riparian Doctrine (Jason Goor, Queensland Farm Bureau, 1981). Water management of necessity, must be at the core of any program to mediate the effects of water shortages that occur during droughts, but political factors can substantially dampen the interest in managing water resources even during droughts.

\section{Framework for State action}

The "Tragedy of the Commons" phenomenon, which characterizes the problems associated with any management plan to mitigate the costs associated with droughts, illustrates that, in the absence of agreement among all the parties affected by the drought, the management responsibility needs to be at the lowest possible level of government that will permit the attainment of management's objectives (Yevjevich et al. [2]). The State, in most situations, represents the unit of government that has the authority to allocate water, to set policy objectives 
that are concerned with water-use efficiency and equity, to consider externalities associated with matters such as minimum in-stream flows, and to coordinate the activities of local governments in meeting water-supply needs during times of severe water shortages.

The responsibility for managing water resources during droughts, once assumed by the State, needs to be vested in such a manner as to require timely action and not be vulnerable to legal challenges by groups who do not favor an approach taken by the State. Although expanding the Governor's powers to deal with disasters by including droughts might be expeditious, the action taken by most States generally is to group management activities with the authority primarily designed to respond to disasters after they have occurred rather than to undertake planning activities to reduce the cost of droughts in advance of their occurrence. Western Australia and Queensland are examples of States that have used executive power to develop statutory guidelines that define droughts and delineate interaction among State agencies responsible for water resources (Hrezo et al. [4]).

\section{Planning tools}

Five planning tools-identification of drought indicators, designation of government authority, notification of the public, curtailment of water use and maintenance of revenues, and monitoring of water-user compliance-to cope with planning for water shortages associated with droughts were developed. These tools addressed the following fundamental questions:

- How does a State know when there is a drought?

- If there is a drought, who is in charge?

- How is the public informed?

- How are current allocations and uses of water to be modified?

- How is compliance assured?

The answers or responses to these fundamental questions need not be identical for each State having a functioning water-management plan applicable to droughts. Each State, however, needs to address each question in terms of its own circumstances. Failure to address each of the questions will detract seriously from the effectiveness of a water-management plan. Each of these planning tools is now examined in detail.

\section{Identification of drought indicators}

Because of the difficulty of deciding when droughts start and end, specific drought indicators must be used to decide when to implement a watermanagement plan. When such indicators have been identified, water users can formulate contingency plans and make decisions on future economic investments (Hrezo et al. [4]). The drought indicators must be precise and susceptible to 
little, if any, subjective decision making. The latter makes the indicators vulnerable to court action by those who oppose advanced planning.

A variety of drought indicators can be used, including the Palmer Index (a drought-severity index), in stream flows, historical data on the present and anticipated needs for water, the degree of subsidence or saltwater intrusion, the potential for irreversible adverse effects on fish and wildlife, and reservoir or ground-water conditions relative to the number of days of water supply remaining (Hrezo et al. [4, p. 47]). Usually it is desirable to select a number of drought indicators to reflect the seasonal relation of sup-ply versus demand. The Delaware River Basin Com-mission (Hrezo et al. [4]), relies on five drought indicators-precipitation, ground-water levels, reservoir storage, stream flow, and the Palmer Index. Ranges of values for each of these indicators are assigned to one of four drought stages-normal, drought watch, drought warning, and drought emergency (Hrezo et al. [4, p. 51]). To activate any one of the drought stages, three of the five drought indicators must indicate a given drought stage (California Department of Water Resources [5, p. 34]). The drought indicators should not be so complex as to cause uncertainty about whether some stage of the water-management plan should be activated; for example, if precipitation and reservoir storage are two drought indicators, the decision to activate the plan will be unclear if the precipitation is less than normal while reservoir storage is normal.

When there is only one source of water supply, one drought indicator may be sufficient; for example, when a city's only source of water is a reservoir, the water-management plan can be activated if reservoir storage, expressed as a percentage of normal seasonal capacity, decreases below a specified percentage. The phasing criteria used by Manchester, Conn., are an example (table 1) - a drought watch goes into effect when reservoir storage is at 70 percent of normal seasonal capacity, and stage I of the water-management plan becomes operational when reservoir storage is 57 percent of normal seasonal capacity.

\section{Monitoring of water-user compliance}

Experience has indicated that reductions in water use greater than 20-25 percent cannot be obtained with a request for voluntary conservation (Western Australia Department of Water Resources [5]). There does not seem to be general agreement as to whether mandatory conservation regulations or water-rate increases and drought surcharges are the most effective means of reducing water use to a volume less than that obtained by voluntary conservation. Western Australia determined that price increases to reduce water use were not as effective as mandatory conservation regulations for a short drought (Western Australia Department of Water Resources [5]). Some utilities managers argue that the availability of enforcement mechanisms is the important feature of the plan and that their application is rare (Western Australia Department of Water Resources [5]). Much of the monitoring of customers for compliance comes from peer-group pressure, but governmental employees, such as supervisors of streets and wastewater departments and inspectors for buildings, plumbing, 
Table 1: Drought-contingency-plan phasing criteria used by two cities in Australia. (Source: Data from Perth Department of Water Resources, 2008, p.33, p.35 and 36).

\begin{tabular}{|c|c|c|c|c|}
\hline \multicolumn{5}{|c|}{$\begin{array}{l}\text { MANCHESTER, CONN. } \\
\text { (South System) }\end{array}$} \\
\hline $\begin{array}{l}\text { Drought } \\
\text { stage }\end{array}$ & $\begin{array}{l}\text { Drought stage initiating } \\
\text { conditions }\end{array}$ & \multicolumn{3}{|c|}{ Demand-reduction objective } \\
\hline $\begin{array}{l}\text { Drought } \\
\text { watch }\end{array}$ & $\begin{array}{l}\text { Reservoir water levels at } 70 \\
\text { percent of normal seasonal } \\
\text { capacity. }\end{array}$ & \multicolumn{3}{|c|}{ Informational only, raise public awareness } \\
\hline Stage 1 & $\begin{array}{l}\text { Reservoir water levels at } 57 \\
\text { percent of normal seasonal } \\
\text { capacity. }\end{array}$ & \multicolumn{3}{|c|}{$\begin{array}{l}\text { Cut back withdrawals from reservoirs by } \\
5 \text { percent or reduce total system use by } \\
3.8 \text { percent. }\end{array}$} \\
\hline Stage 2 & $\begin{array}{l}\text { Reservoir water levels at } 40 \\
\text { percent of normal seasonal } \\
\text { capacity. }\end{array}$ & \multicolumn{3}{|c|}{$\begin{array}{l}\text { Cut back withdrawals from reservoirs by } \\
30 \text { percent or reduce total system use by } \\
20 \text { percent. }\end{array}$} \\
\hline Stage 3 & $\begin{array}{l}\text { Reservoir water levels at } 0 \\
\text { percent of normal seasonal } \\
\text { capacity }\end{array}$ & \multicolumn{3}{|c|}{$\begin{array}{l}\text { Eliminate withdrawals from reservoirs } \\
\text { and reduce total system use by } 70 \text { percent. }\end{array}$} \\
\hline \multicolumn{5}{|c|}{$\begin{array}{l}\text { Perth, WA, WATER DEPARTMEN } \\
\text { (Deficit reduction objective is based on demand levels in a 1-in- } \\
\text { are expected to be above normal averages due to warm, }\end{array}$} \\
\hline \multicolumn{5}{|c|}{ Summer-shortage response plan } \\
\hline & & & $\begin{array}{l}\text { Demand-reduction } \\
\text { amount, in million } \\
\text { gallons per day }\end{array}$ & \\
\hline $\begin{array}{l}\text { Stage } 1 \\
\text { Minor } \\
\text { shortage } \\
\text { potential }\end{array}$ & \multicolumn{2}{|c|}{$\begin{array}{l}\text { Total system storage is not filled to capacity as } \\
\text { of June } 1 . \text { Streamflow and snowmelt forecasts } \\
\text { indicate that inflows will be inadequate to fill } \\
\text { storage facilities before the beginning of the } \\
\text { peak-use season. }\end{array}$} & $\begin{array}{l}\text { Water-system } \\
\text { management } \\
\text { Customer } \\
\text { Total }\end{array}$ & $\begin{array}{l}0.0 \\
3.0\end{array}$ \\
\hline $\begin{array}{l}\text { Stage } 2 \\
\text { Moderate } \\
\text { shortage } \\
\text { potential }\end{array}$ & \multicolumn{2}{|c|}{$\begin{array}{l}\text { Total system storage is predicted to fall below } \\
\text { the level required to meet expected demands } \\
\text { during a 1-in- } 50 \text {-year drought. System inflows } \\
\text { continue to be low. Weather forecasts predict a } \\
\text { continuing trend of warmer, drier than normal } \\
\text { conditions. }\end{array}$} & $\begin{array}{l}\text { Water-system } \\
\text { management } \\
\text { Customer } \\
\text { Total }\end{array}$ & $\begin{array}{l}4.7 \\
7.7\end{array}$ \\
\hline $\begin{array}{l}\text { Stage } 3 \\
\text { Serious } \\
\text { shortage }\end{array}$ & \multicolumn{2}{|c|}{$\begin{array}{l}\text { Total system storage drops below the level } \\
\text { required to meet expected demands during a 1- } \\
\text { in- } 50 \text {-year drought. System inflows continue to } \\
\text { be low. Weather forecasts predict a continuing } \\
\text { trend of warmer, drier than normal conditions. }\end{array}$} & $\begin{array}{l}\text { Water-system } \\
\text { management } \\
\text { Customer } \\
\text { Total }\end{array}$ & $\begin{array}{l}15.0 \\
20.0\end{array}$ \\
\hline
\end{tabular}


Table 1: $\quad$ Continued.

\begin{tabular}{|c|c|c|c|}
\hline $\begin{array}{l}\text { Stage } 4 \text { Severe } \\
\text { shortage }\end{array}$ & $\begin{array}{l}\text { Conditions described for stage } 3 \text { occur near } \\
\text { the end of the peak-use season. }\end{array}$ & $\begin{array}{l}\text { Water-system } \\
\text { management } \\
\text { Customer } \\
\text { Total }\end{array}$ & $\begin{array}{l}5.0 \\
16.1 \\
21.1\end{array}$ \\
\hline $\begin{array}{ll}\text { Stage } & 5 \\
\text { Critical } & \\
\text { emergency } & \end{array}$ & $\begin{array}{l}\text { Customer demands and system pressure } \\
\text { requirements cannot be met. }\end{array}$ & Not applicable. & \\
\hline \multicolumn{4}{|c|}{ Fall-shortage response plan } \\
\hline & & $\begin{array}{l}\text { Demand-reduction } \\
\text { amount, in million } \\
\text { gallons per day }\end{array}$ & \\
\hline $\begin{array}{l}\text { Stage } 1 \text { Minor } \\
\text { shortage } \\
\text { potential }\end{array}$ & $\begin{array}{l}\text { Total system-storage levels are dropping due } \\
\text { to the increased use associated with a warm, } \\
\text { dry summer. Weather forecasts predict a } \\
\text { continuing trend of warmer, drier than } \\
\text { normal conditions. }\end{array}$ & $\begin{array}{l}\text { Water-system } \\
\text { management } \\
\text { Customer } \\
\text { Total }\end{array}$ & $\begin{array}{l}3.0 \\
0.0 \\
3.0\end{array}$ \\
\hline $\begin{array}{l}\text { Stage } 2 \\
\text { Moderate } \\
\text { shortage } \\
\text { potential }\end{array}$ & $\begin{array}{l}\text { Total system storage is expected to fall } \\
\text { below the level required to meet expected } \\
\text { demands during a } 1 \text {-in- } 50 \text {-year drought. }\end{array}$ & $\begin{array}{l}\text { Water-system } \\
\text { management } \\
\text { Customer } \\
\text { Total }\end{array}$ & $\begin{array}{l}5.0 \\
2.4 \\
7.4\end{array}$ \\
\hline $\begin{array}{l}\text { Stage } 3 \\
\text { Serious } \\
\text { shortage }\end{array}$ & System inflows continue to be low. & $\begin{array}{l}\text { Water-system } \\
\text { management } \\
\text { Customer } \\
\text { Total }\end{array}$ & $\begin{array}{l}5.0 \\
6.2 \\
11.2\end{array}$ \\
\hline $\begin{array}{l}\text { Stage 4 Severe } \\
\text { shortage }\end{array}$ & $\begin{array}{l}\text { Weather forecasts predict a continuing trend } \\
\text { of warmer, drier than normal conditions. }\end{array}$ & $\begin{array}{l}\text { Water-system } \\
\text { management } \\
\text { Customer } \\
\text { Total }\end{array}$ & $\begin{array}{l}5.0 \\
19.6 \\
24.6\end{array}$ \\
\hline $\begin{array}{l}\text { Stage } 5 \\
\text { Critical } \\
\text { emergency }\end{array}$ & $\begin{array}{l}\text { Customer demands and system pressure } \\
\text { requirements cannot be met. }\end{array}$ & $\begin{array}{l}\text { Water-system } \\
\text { management } \\
\text { Customer } \\
\text { Total }\end{array}$ & $\begin{array}{l}5.0 \\
52.4 \\
57.4\end{array}$ \\
\hline
\end{tabular}


electric, construction, and health services can be empowered to issue citations (Western Australia Department of Water Resources [5]). This is an effective method of monitoring a service area with a minimum of expense and with minimal disruption of employees' regular work schedules.

\section{Intrastate regional authorities and interstate commission compacts}

Intrastate regional authorities can perform the water-management function during droughts if droughts are less than statewide in scope. Politically, such authorities are difficult to create because of the rivalry that exists among local units of government. If intrastate regional authorities are established, such regional grouping must be done carefully to avoid possible constitutional challenge as unlawful delegation of legislative authority (Hrezo et al. [4]). The water-management districts in Florida are examples of this approach.

When droughts affect more than one State but are not national in scope, interstate commissions and compacts can provide the management function to mitigate drought effects. Their effectiveness is predicated on having wellpublicized plans and specific rules for planning purposes so that all users know how they will fare when the river flows cannot accommodate all the withdrawal demands (Hrezo et al. [4]).

\section{Government responsibilities for water quality as related to droughts}

Since 1982, with the passage of the Water Pollution Control Act Amendments (Public Law 92-500), the Federal Government has assumed a more dominant role on water-quality issues related to surface water. Because droughts and the resulting low flows have a substantial effect on water quality, it is possible, on the basis of existing legislation and regulations, that the Federal Government might become more interested in drought management. For example, section 208(b)(2)(1) of the Clean Water Act (Public Law 92-500) provides:

Any plan prepared under such process shall include, but not be limited to, (1) a process to (i) identify, if appropriate, salt water intrusion into rivers, lakes, and estuaries resulting from reduction of fresh water flow from any cause, including irrigation, obstruction, ground water extraction, and diversion, and (ii) set forth procedures and methods to control such intrusion to the extent feasible where such procedures and methods are otherwise a part of the waste treatment management plan.

Salt water intrusion no less than point sources of discharge, alters significantly the character of the water and the life system it supports. Salt water intrusion often devastates the commercial shellfish industry. It must be accounted for and controlled in any pollution control program. It makes no sense to control salts associated with industrial or municipal waste point sources and allow, at the same time, similar effects to enter the fresh water as a result of 
intrusion of salt water. Fresh water flows can be reduced from any number of causes. The bill requires identification of those causes and establishment of methods to control them so as to minimize the impact of salt water intrusion.

Droughts can be one of the major causes for reduced freshwater flows, and the law requires that methods be established to control or to minimize the causes of reduced freshwater flows that allow saltwater intrusion.

The requirement under the Safe Drinking Water Act (Public Law 93-523) contains language that can be construed to include drought conditions and, thus, impose on States the requirement to adapt criteria that include drought conditions:

Before a person may enter into a financial commitment for or initiate construction of a new public water system or increase the capacity of an existing public water system, he shall notify the State and, to the extent practicable, avoid locating part or all of the new or expanded facility at a site which: (a) Is subject to a significant risk from earth-quakes, floods, fires or other disasters which could cause a breakdown of the public water system or a portion thereof; or ***. Lastly, the quality of surface-water bodies is affected markedly by the runoff that occurs when precipitation increases after a drought. During the drought, pollutants accumulate on the land surface and on other surfaces, such as pavement and structures. It is not uncommon for droughts to be followed by a period of abnormally high precipitation that tends to aggravate the already existing water-quality problems by rapidly flushing large loads of pollutants into surface-water bodies. After the drought in England in the 1970s, the nitrate concentration in the Thames River increased to the point where the public-supply intakes had to be closed (Blackburn [6, p. 54]). This kind of post drought problem may be reflected in what the Government requires States to do to meet water-quality standards. Some drought planning may occur at the State level as an action taken to address this water-quality problem.

\section{Conclusions}

The planning for and the management of the effects of droughts appear to have a low priority in all but a few States, although all have experienced severe water shortages. For the most part, accommodating the inconvenience caused by droughts is considered a local-government responsibility. The Government's role has been to provide financial assistance to citizens after the droughts have occurred. Water-quality legislation may cause the Federal Government to take a more proactive approach to managing the effects of droughts. Several factors will have to coexist before many States will undertake development of plans to mitigate the effects of droughts. Such factors may be the occurrence of a drought that is long and extensive, thereby increasing demands on a fixed water supply, and a public awareness of the economic costs of droughts. As water demands continue to grow, even minor droughts will become more serious, and States will be compelled to become leaders in developing water-management plans. 


\section{References}

[1] Palmer, W.C., 1997, Meteorological drought: Weather Bureau Research Paper 45, $64 \mathrm{p}$.

[2] Yevjevich, Vujica, Hall, W.A., and Salas, J.D., eds., 1978, Drought research needs - Conference on drought research needs, Colorado State University, Fort Collins, Colo., December 12-15, 1977, Proceedings: Fort Collins, Colo., Water Resources Publications, p. 288

[3] Heathcode, R.L., 1986, Drought mitigation in Australia: Great Plains Quarterly, v. 6, p. 225-237.

[4] Hrezo, M.S., Bridgeman, P.G., and Walker, W.R., 1986a, Integrating drought planning into water resources management: Natural Resources Journal, v. 26p. 141-167.1986b, Managing droughts through triggering mechanisms: American Water Works Association Journal, v. 1986, p. 4651.

[5] Western Australia Department of Water Resources, 1988, Urban drought guidebook: Western Australia Department of Natural Resources, Department of Water Resources, Office of Water Conservation, Water Conservation Guidebook 7,144 p.

[6] Blackburn, A.M., 1978, Management strategies-Dealing with drought: American Water Works Association Journal, v. 1978, p.51-59.

[7] Cox, W.E., 1982, Water law primer: American Society of Civil Engineers, Water Resources Planning and Management Division, Proceedings, v. 18 (WRI), p. 107-122.

[8] Harrison, Robert, 1977, Response to droughts: Water Spectrum, v. 9, no. 3, p. 34-41.

[9] Sheer, D.P., 1986, Managing water supplies to increase water availability, in National water summary 1985-Hydrologic events and surface-water resources: U.S. Geological Survey Water-Supply Paper 2300, p. 101-112.

[10] Westcoat, J., White, G., 2009, Water for life: Water management and environmental policy 